\title{
PELAYANAN PERIZINAN SECARA ELEKTRONIK SEBAGAI \\ UPAYA MEMBERIKAN KEPASTIAN HUKUM DALAM \\ MELAKUKAN INVESTASI ${ }^{1}$
}

\author{
Sentosa Sembiring \\ Fakultas Hukum Universitas Katolik Parhyangan (UNPAR) \\ J1. Ciumbuleuit No 94 Bandung 40141 \\ sentosa@unpar.ac.id; Tlp. (022) 2033097
}

\begin{abstract}
In creating an investment climate to compete with other countries, various efforts have been made by the government, including simplifying the licensing process by issuing Government Regulation Number 24 of 2018 concerning Electronically Integrated Business Licensing Services (government regulation). The problem is whether the existence of these regulations can immediately solve licensing problems? This normative research using a statutory approach is collected through secondary data sources. As a result, the issuance of the government regulation is the first step in an effort to speed up the licensing process for investing. However, other efforts are needed so the presence of investors can increase, namely by equalizing the perceptions of all parties related to investment, so that the regulations issued do not conflict with each other. With synchronization, investors will get legal certainty and guarantees in carrying out their investments.
\end{abstract}

Key words: Investment, Integrated Licensing, Legal Certainty

\begin{abstract}
ABSTRAK
Dalam menciptakan iklim ivestasi agar bisa berdaya saing dengan negara lain, berbagai upaya dilakukan oleh pemerintah, termasuk menyederhanakan proses perizinan dengan menerbitkan Peraturan Pemerintah Nomor 24 Tahun 2018 Tentang Pelayanan Perizinan Berusaha Terintegrasi Secara Elektronik (PP No.24/2018). Permasalahannya apakah keberadaan peraturan tersebut dapat serta merta mengatasi persoalan perizinan? Penilitian normatif ini meggunakan pendekatan peraturan perundang-undan dengan menggunakan sumber data sekunder. Hasilnya, diterbitkannya PP No. 24/2018 merupakan langkah awal dalam upaya untuk mempercepat proses perizinan untuk melakukan investasi. Namun, diperlukan upaya lain agar kehadiran investor dapat semakin meningkat yakni dengan menyamakan persepsi dari semua pihak yang terkait investasi, sehingga peraturan yang diterbitkan tidak saling berbenturan. Dengan adanya sinkronisasi maka investor mendapat kepastian dan jaminan hukum dalam menjalankan investasi.
\end{abstract}

Kata kunci: Investasi, Perizinan Tertegrasi, Kepastian Hukum

1 Materi ditulis kembali dari Makalah yang telah dipresentasikan dalam Konfrensi Nasional Hukum Bisnis dengan tema: "Pengintegrasian Hukum dan Etika ke dalam Corporate Governance”. Penyelenggara: Fakultas Hukum Universitas Brawijaya. Malang, 14-16 Oktober 2019. 


\section{Latar Belakang}

Dalam dekade terakhir ini, persaingan antarnegara dalam menarik investor agar bersedia menanamkan modalya di negara yang bersangkutan penuh dengan tantangan. Tantangan yang dimaksud di sini, tidak saja datang dari luar yakni negara tuan rumah itu sendiri yakni memberi berbagai kemudahan dalam melakukan investasi, akan tetapi juga dari dalam negeri sendiri yakni belum tersinkronisasinya berbagai peraturan perundang-undangan yang terkait dengan penanaman modal, baik yang diterbitkan oleh pemerintah pusat maupun oleh pemerintah daerah. Munculnya berbagai hambatan dalam menjalankan kegiatan bisnis dalam hal ini melakukan kegiatan investasi dari hasil studi yang dilakukan oleh Wieky Rusmanto terlihat bahwa, secara umum hambatan, permasalahan dan kondisi perizinan yang terjadi di Indonesia, khususnya di daerah setelah dikeluarkannya kebijakan otonomi daerah yakni: pertama, belum adanya sistem perizinan yang baku, integratif dan komprehensif; kedua, banyaknya berbagai instansi yang mengeluarkan izin; ketiga, tersebarnya peraturan tentang perizinan dalam berbagai peraturan perundang-undangan; dan keempat, diadakannya suatu izin hanya didasarkan semata-mata kepada tujuan pemasukan bagi pendapatan pemerintah (terutama setelah diberlakukannya konsep otonomi daerah). ${ }^{2}$ Sementara itu izin suatu hal yang tidak bisa dihindari agar kegiatan usaha yang dijalankan tidak dikualifikasikan sebagai kegiatan usaha yang tidak sah (illegal). Dengan demikian setiap pengusaha wajib untuk mengurus dan memiliki izin usaha dari instansi pemerintah yang sesuai dengan bidangnya masing-masing. ${ }^{3}$

Dari apa yang dikemukakan oleh peneliti di atas dapat dipahami betapa rumit dan birokratisnya untuk melakukan investasi di negeri ini. Kondisi tersebut tentu kurang menguntungkan dalam mengundang investor. Seperti diketahui investor terlebih lagi yang berstatus sebagai perusahaan multinasional, ketika melakukan investasi ada kepasttian hukum. Hal ini dapat dimaklumi, mengingat investasi yang dilakukan oleh investor dalam waktu yang cukup panjang. Selain itu modal yang ditanamkan oleh invsetor tidak selalu dalam uang tunai namun berupa benda tidak berwujud yaitu hak kekayaan intelektual (intlectual property rights). Untuk mendapatkan jenis hak ini butuh biaya juga. Untuk itu pihak investor berharap mendapatkan perlindungan hukum di negara tempat ia melakukan investasi. ${ }^{4}$

2 Wieky Rusmanto. Evaluasi Kebijakan Pelayanan Perizinan Dan Non Perizinan Kota/Kabupaten Di Wilayah Provinsi Jawa Barat Termuat di Jurnal Ilmiah Magister Ilmu Administrasi (JIMIA) No.2 Tahun XI Juni 2017.

3 Santhy Ainun Adrianty, dkk. "Kewenangan Badan Koordinasi Penanaman Modal Pasca Berlakunya OSS", Jurnal Perspektif Hukum Vol. 19, No.2, (November 2019): 250-262. Tersedia file://C:/Users/Acer/AppData/ Local/Temp/209-384-1-SM.pdf, diaskses 24 November 2020

4 Dalam kaitannya dengan Hak Kekayaan Intelektual,Pemerintah Indonesia terus melakukan pembaharuan peraturan perudang-undangan tentang hal ini, antara lain diterbitkannya: Undang-Undang Nomor 28 Tahun 2014 Tentang Hak Cipata; Undang-Undang Nomor 20 Tahun 2016 Tentang Merek dan Indikasi Geografis; Undang-Undang Nomor 13 Tahun 2016 Tentang Paten. 
Untuk mengatasi berbagai hambatan tersebut, berbagai upaya pun telah dilakukan oleh pemerintah, antara lain Pemerintah telah melakukan pembaharuan landasan hukum dalam bidang penanaman modal yakni dengan menerbitkan Undang-Undang Nomor 25 Tahun 2007 Tentang Penanaman Modal yang diundangkan pada tanggal 26 April 2007, Lembaran Negara Republik Indonesia Tahun 2007 Nomor 67 (selanjutnya disebut UUPM). Sebagai tindak lanjut terbitnya UUPM, pemerintah memberikan pelayanan terpadu satu atap. Bila merujuk kepada konsep pelayanan satu atap seharusnya bisa menjadi model pelayanan dan pemberian izin sehingga para investor tidak direpotkan atau merasa dipermainkan oleh instansi terkait. ${ }^{5}$ Namun, tampaknya upaya yang dilakukan dalam memberikan layanan perizinan dalam satu atap cukup ideal. Akan tetapi dalam kenyataan masih banyak kendala, mengapa? Karena, layanan perizinan yang ada saat ini bersifat lintas sectoral baik dalam tingkatan UndangUndang, Peraturan Pemerintah, maupun Peraturan Menteri/Kepala Lembaga. Dengan banyaknya perizinan dan prosedur yang harus dilalui oleh penanam modal, dampaknya bisa dibayangkan peringkat kemudahan berusaha di Indonesia kalah bersaing dengan negara lain. ${ }^{6}$
Menyadari akan hal ini, pemerintah pun melakukan terobosan yakni menata ulang berbagai peraturan yang dianggapmenghambat kegiatan investasi lewat kebijakan Omnibus Law. Ada pun tujuan yang hendak dicapai melalui penataan regulasi ini tiada lain untuk menghilangkan tumpang tindih antar peraturan perundang-undangan. Melalui penataan regulasi dengan metode Omnibus Law dapat dilakukan berupa pemangkasan, penyederhanaan, dan penyelerasaan atas undang-undang yang telah ada. ${ }^{7}$

Munculnya kebijakan tersebut, tampaknya bukanlah datang secara tiba-tiba. Bila diikuti dari berbagai informasi yang disampaikan oleh pemerintah, kebijakan tersebut sudah sudah melewati proses kajian yang cukup mendalam dengan mengadakan pertemuan dengan berbagai pihak. Hal ini tentu beralasan, karena pada saat UUPM diterbitkan, timbul secercah harapan, dengan hadirnya undang-undang ini akan lebih mudah untuk menarik investor agar bersedia menanamkan modalnya di Indonesia. Namun, dalam pelaksanaan undang-undang tersebut terdapat berbagai kendala khususnya yang terkait dengan masalah perizinan untuk berinvestasi tidak selalu berjalan sesuai dengan apa yang diharapkan, terlebih lagi di rezim berlakunya otonomi daerah dirasakan cukup

5 Firman Freaddy Busroh. "Konseptualisasi Omnibus Law Dalam Menyelesaikan Permasalahan Regulasi Pertanahan”. Jurnal Arena Hukum Vol. 10, No.2, (Agustus 2017): 227-250. Tersedia https://arenahukum. ub.ac.id/index.php/arena/article/viewFile/327/269, diakses 24 November 2020

6 Muhammad Baidarusa, Chintya Dewi Nimas Ayu Anggraeni dan Hazada Zafira Mauliza. "Tinjauan Atas regulasi Penanaman Modal Guna Meningkatkan Ketertarikan Investasi Infrastruktur Strategis Di Indonesia." Jurnal BPPK Vol.11, No.1, (2018): 75-86. Tersedia di file://C:/Users/Acer/AppData/Local/Temp/163Article\%20Text-1444-1-10-20180823.pdf, diakses 24 November 2020

7 Muhammad Insa Ansari. “Omnibus Law Untuk Menata Regulasi Penanaman Modal." (Omnibus Law For Arranging Investment Regulation). Jurnal RechtsVinding Vol. 9, No. 1, (April 2020): 77 Tersedia di https:// rechtsvinding.bphn.go.id/artikel/5.\%20Muhammad\%20Insa\%20Ansari.pdf, diakses 24 November 2020 
banyak masalah perizinan yang harus diurus oleh calon investor. Sebagaimana dapat dibaca dalam berbagai studi yang dilakukan oleh berbagai pihak, antara lain Ali Amrin, Dadang Abdullah, M. Yasir Said mengemukakan, hal lain yang juga sering dikeluhkan oleh banyak investor adalah pelayanan perizinan dan birokrasi yang masih dianggap berbelit-belit dan memakan biaya yang besar. ${ }^{8}$

Apa yang dikemukakan oleh para penulis di atas, tampaknya masalah perizinan dalam menjalankan investasi, salah satu yang menjadi bahan pertimbangan bagi calon investor, apakah proses pengurusan perizinan dalam melakukan investasi mudah atau berbelit-belit karena harus mengikuti berbagai proses. Pertimbangan yang demikian tentu dapat dimaklumi, karena bagi pebisnis selain masalah biaya yang menjadi pertimbangan juga masalah waktu yang ditentukan dalam mengurus berbagai perizinan yang dibutuhkan, apakah ada tenggat waktu yang bisa ditentukan berapa lama waktu yang harus ditunggu. Hal ini tentu penting bagi pelaku usaha, sebab semua kegiatan yang dilakukan harus dihitung secara cermat dan tentunya dengan perhitungan bisnis untung rugi (cost and benefit). Dalam kaitan ini menarik menyimak apa yang dikemukakan oleh Iqbal Damanik, banyaknya izin yang harus diurus, bukan hanya menjadi beban bagi dunia usaha, akan tetapi juga menambah beban kerja Pemerintah. Karenanya, upaya pengurangan jenis izin merupakan satu langkah penting dalam kebijakan reformasi birokrasi perizinan khususnya untuk meningkatkan iklim investasi yang kondusif. ${ }^{9}$ Jadi tampak di sini, bahwa masalah perizinan merupakan hal penting yang harus tuntaskan agar kegiatan dunia usaha yang diharafkan dapat bergerak ke daerah, bisa segera terwujud.

Jika demikian halnnya apa yang harus dilakukan? Melihat perubahan lingkungan bisnis (environment of business) dewasa ini berubah dengan cepat, tidak saja dalam tataran lokal manun juga dalam tataran global, maka dirasakan penting untuk melakukan berbagai pembenahan dalam menarik calon investor terutama dalam bidang pelayanan perizinan yang dianggap sangat lamban dan rantai birokrasi yang harus dilalui oleh pemodal. Hal ini tentu kurang menguntungkan, sebab bagi pebisnis bila tempat untuk melakukan kegiatan bisnis tidak menguntungkan akan ditinggalkan. Untuk itu, perlu disadari bahwa, di era masa kini yang disebut juga sebaga era teknologi informasi, sudah saatnya untuk mengelola pelayanan kegiatan bisnis tidak lagi dilakukan secara manual dengan tatap muka, akan tetapi dengan menggunakan teknologi informasi. Dengan menggunakan teknologi informasi, tidak perlu melakukan tatap muka

8 Ali Amrin, dkk., "Kebijakan Pemerintah Yang Menjamin Kepastian Hukum Dalam Berinvestasi Di Daerah." Prosiding Seminar Nasional Lingkungan Lahan Basah Vol. 4, No. 2 (April 2019.): 371, diakases 1 Juni 2019, doi: https://snllb.ulm.ac.id/prosiding/index.php/snllb.../216.

9 Iqbal Damanik. "Deregulasi Izin: Melanjutkan Reformasi Perizinan di Daerah". KPPOD Brief Membangun Indonesia dari Daerah. (Januari-Maret 2015): 4, diakses 1 Juli 2019, doi: https://www.kppod.org/brief/ download?id=22, 
antara yang melayani dan yang dilayani. Selain itu, bagi aparat birokrasi sudah saatnya pula mengubah paradigma dari minta dilayani menjadi pelayan masyarakat (public servant) dalam arti luas.

Tampaknya paradigma di atas yang hendak diubah oleh pemerintah. Dengan memberikan pelayanan yang tepat akan mendapatkan manfaat yang tepat pula. Dalam hal inilah teori investasi akan menjadi kenyataan, tujuan negara nengundang investor yakni untuk membuka lapangan kerja, alih teknologi dan mendapatkan devisa. Oleh karena itu, berbagai upaya pun dilakukan oleh pemerintah dalam mengundang investor yakni dengan menerbitkan serangkaian kebijakan dalam mempercepat proses perizinan dalam melakukan kegiatan investasi. Untuk itu, pemerintah menerbitkan Peraturan Presiden Republik Indonesia Nomor 91 Tahun 2017 Tentang Percepatan Pelaksanaan Berusaha (Perpres No 91/2017). Ada pun tujuan diterbitkannya Perpres No 91/2017 dikemukakan sebagai berikut: pertama meningkatkan standar pelayanan perizinan berusaha yang efisien, mudah, dan terintegrasi tanpa mengesampingkan tata kelola Pemerintahan yang baik; kedua, mempercepat proses penerbitan perizinan berusaha sesuai dengan standar pelayanan; ketiga, memberikan kepastian waktu dan biaya dalam proses perizinan berusaha; keempat, meningkatkan koordinasi dan sinkronisasi kementerian/lembaga dan pemerintah daerah dalam proses pemberian perizinan berusaha; kelima, menyelesaikan hambatan dalam proses pelaksanaan berusaha; dan keenam, memanfaatkan teknologi informasi dalam proses perizinan berusaha melalui penerapan sistem perizinan terintegrasi (single submission). Menilik dari tujuan diterbitkannya Perpres tersebut, terlihat upaya yang hendak dilakukan oleh pemerintah agar proses perizinan dalam menjalankan usaha memerlukan sebuah terobosan dalam hal ini dengan menanfaatkan tekonologi informasi. Pelayanan pun dilakukan secara terintegrasi secara elektornik.

Untuk merealisasikan layanan elektrorik tersebut, berbagai tahapan pun telah dilakukan oleh pemerintah dalam mengoperasikan pelayanan perizinan secara terpadu dan puncaknya adalah, pemerintah menerbitkan Peraturan Pemerintah Republik Indonesia Nomor 24 Tahun 2018 tentang Pelayanan Perizinan Berusaha Terintegrasi Secara Elektronik atau (PP 24/2018) atau dikenal juga dengan Online Single Submission (OSS). Pasca berlakunya Sistem OSS dalam rangka menunjang ease of doing business (EODB) ternyata berkorelasi secara signifikan dalam menaikkan peringkat kemudahan perizinan di Indonesia. ${ }^{10}$

Jika demikian, apa latar belakang diterbitkannya PP 24/2018? Hal ini dijelaskan dalam konsideran sebagai berikut: bahwa

10 Desi Arianing Arrum. "Kepastian Hukum Dalam Perizinan Berusaha Terintegrasi Secara Elektronik (Online Single Submission) di Indonesia" Jurnal Jurist-Diction Vol. 2, No. 5, (September 2019). Termuat di https://ejournal.unair.ac.id/JD/article/view/15222, unduh 24 November2020, diakses 24 November 2020. 
dalam rangka percepatan dan peningkatan penanaman modal dan berusaha, perlu menerapkan pelayanan Perizinan Berusaha terintegrasi secara elektronik. ${ }^{11}$ Apa yang ditegaskan dalam latar belakang terbitnya peraturan pemerintah tersebut secara tersurat telah dikemukakan yakni untuk mempercepat proses perizinan berusaha yang dilakukan secara elektronik. Tegasnya dalam Pasal 1 angka 5 PP 24/2018 dikemukakan: Perizinan Berusaha Terintegrasi Secara Elektronik atau Online Single Submission yang selanjutnya disingkat OSS adalah Perizinanan berusaha yang diterbitkan oleh lembaga OSS untuk dan atas nama menteri, pimpinan lembaga, gubernur, atau bupati/wali kota kepada Pelaku Usaha melalui sistem elektronik yang terintegrasi.

Merujuk kepada pengertian yang dijabarkan dalam ketentuan di atas, adalah beralasan jika dikemukakan di sini secara normatif tentunya masalah perizinan bukan lagi hal yang menjadi hambatan bagi investor dalam menjankan usaha. Disebut demikian, karena masalah perizinan berusaha telah terintegrasi secara elektronik yang dikelola oleh lembaga OSS. Hal ini tentunya adalah sebuah terobosan yang cukup penting dalam memotong rantai birokrasi yang selama ini cukup panjang dalam pengurusan perizinan dapat dilakukan oleh satu lembaga OSS sehingga dapat meningkatkan kepercaya calon investor. Sebagaimana dikemukakan oleh pakar investasi, melalui OSS ini, Pemerintah berharap peringkat $E O D B$ Indonesia bisa meningkat dan menjadikan Indonesia sebagai primadona tujuan investasi dunia. ${ }^{12}$

Jika dilihat dari sudut pandang ini, tidaklah berlebihan bila dikemukakan kehadirian lembaga OSS sebagai pelayanan perizinan secara elektronik sesuatu yang sangat ideal. Dengan kata lain, kehadiran OSS dapat mempercepat proses perizinan dalam melakukan investasi. Asumsinya adalah semua pihak yang terkait dengan masalah perizinan sudah memahami apa yang harus dikerjakan dalam mencapai tujuan yang dimaksud. Namun jika dilihat dari sudut pandang lain, yang menjadi pertanyaan adalah apakah tujuan yang hendak dicapai dengan diterbitkannya pengaturan tentang pelayanan perzinan usaha secara elektronik para pihak yang terkait dengan masalah perizinan telah mempunyai pemahaman yang sama baik dari tujuan yang hendak dicapai maupun ketersediaan sumber daya manusia dan teknologi yang akan digunakan? Di sisi lain, ada hal yang kiranya juga perlu diperhatikan adalah apakah dengan diterbitkannya peraturan pemerintah tersebut secara substansial tidak berbenturan dengan peraturan daerah? Dengan kata lain dengan diberlakukannya undang-undang

11 Konsiderans butir a Peraturan Pemerintah Republik Indonesia Nomor 24 Tahun 2018 tentang tentang Pelayanan Perizinan Berusaha Terintegrasi Secara Elektronik.

12 Irna Nurhayati, dkk. "Pendaftaran Badan Usaha Secara Elektronik Pasca Diterbitkannya Peraturan Pemerintah Nomor 24 Tahun 2018”. (Electronic Registration of Business Post-Issuance of the Government Regulation Number 24 of 2018)" Jurnal Negara Hukum Vol. 10, No. 2, (November 2019): 168. $\quad$ file:///C:/Users/Acer/ AppData/Local/Temp/1351-3845-1-PB.pdf, diakases 24 November 2020 
pemerintahan daerah, pemerintah daerah diberi kewenangan untuk menerbitkan peraturan daerah. Dalam kaitan ini menarik menyimak apa yang dikemukakan oleh Jimmy Z. Usfunan, lahirnya PP 24/2018 tidak secara otomatis mencabut perda yang sudah diterbitkan di daerah karena akan menyalahi asas otonomi daerah. Sebagai pihak yang menerbitkan Perda, pemerintah daerah bersama dengan DPRD memilki kewenangan untuk mencabut aturan-aturan tersebut. ${ }^{13}$

Apa yang dikemukakan oleh pakar hukum tata negara di atas, tentunya hal tersebut merupakan sebuah pemikiran yang cukup substansial, kiranya perlu mendapat kajian yang lebih mendalam agar kehadiran OSS sebagai lembaga yang mempermudah dalam pelayanan kegiatan berusaha agar tidak terjadi tumpang tindih dalam menjalankan kewenangan yang secara yuridis mendapatkan legalitas. Jika tejadi demikian, pada akhirnya dapat menimbulkan permasalahan tersendiri dalam pelaksanaannya di lapangan. Sebagaimana dapat dibaca di laporan Tim Peneliti KPPOD, belum optimalnya diseminasi dan pemahaman Pemerintah Daerah akan perubahan di tingkat nasional. Hal ini berdampak sejumlah Peraturan Daerah (Perda) yang tidak up to date dengan regulasi nasional yang baru. Kondisi ini berefek lanjut pada ketentuan tarif yang sudah berubah atau ditiadakan. Selain itu, sejumlah perda bermasalah muncul karena ketidakpahaman dan misinterpretasi pemda atas regulasi nasional. Regulasi pusat masih belum optimal (kualitas pengaturan, tumpang tindih dan inkonsistensi). Kondisi ini tidak memberikan kepastian hukum dan kerangka kebijakan yang jelas terkait kemudahan berusaha di daerah. ${ }^{14}$ Apa yang dikemukakan oleh tim peneliti KPPOD ini, semakin menguatkan pemikiran dalam mengundang investor selain perlu ada kepastian hukum juga perlu ada kesamaan pandang dari berbagai pihak bahwa kehadiran investor ke negeri ini sangat dibutuhkan dalam rangka menggerakkan perekonomian nasional.

Bertitik tolak dari latar belakang di atas, rumusan masalah dapat dikemukan sebagai Apakah dengan diterbitkannya Peraturan Pemerintah Nomor 24 Tahun 2018 Tentang Pelayanan Perizinan Berusaha Terintegrasi Secara Elektronik, pelayanan perizinan dalam melakukan investasi dengan sendirinya akan menghilangkan berbagai hambatan yang dalam melakukan investasi? Dan Upaya apa yang harus dilakukan untuk mengatasi berbagai hambatan dalam melakukan pelayanan investasi secara elektronik sehingga mendapat manfaat tidak saja bagi investor namun juga bagi pemerintah dan manyarakat?

Metode penelitian yang digunakan dalam penelitian adalah metode penelitian yuridis normatif. Adapun alasan yang mendasari

13 Lihat hukumonline edisi Kamis, 12 Juli 2018. "Potensi Masalah Hukum Pasca Terbitnya PP Perizinan Terintegrasi".

14 Tim Peneliti KPPOD, "Regulasi Usaha di Daerah Kajian Perda Pungutan dan Perizinan.” (2017): 21 https:// www.kppod.org/backend/files/laporan_penelitian/kajian-perda-pungutan-dan-perizinan.pdf, , diakses 13 Agustus 2019 
digunakannya metode ini, karena yang dijadikan sebagai obyek penelitian adalah peraturan perundang-undangan yang terkait dengan masalah perizinan dalam melakukan investasi yang dilakukan secara elektronik. Adapun sumber data yang digunakan adalah data sekunder.

\section{PEMBAHASAN}

\section{A. Penerbitan Peraturan Pemerintah Nomor 24 Tahun 2018 Sebagai Upaya Untuk Mempercepat Pelayanan Perizinan Ivestasi}

Disadari atau tidak di era masa kini, upaya dalam menarik calon investor agar bersedia menamamkan modalnya di negeri ini atau tepatnya di daerah yang secara terus menerus dipromosikan oleh pimpinan negeri ini maupun oleh kepala darah baik di dalam forum formal maupun dalam berbagai kesempatan informal, inilah saatnya untuk berivestasi. Di balik ajakan ini, memang disadari bahwa untuk mengundang investor agar bersedia menanamkan modalnya memang tidaklah mudah, terlebih lagi di hari-hari terakhir ini sedang dilanda oleh pandemi Covid-19 tantangan yang dihadapi semakin berat. Negara lain pun berjuang dengan berbgai cara untuk mengajak investor untuk berinvestasi di negaranya dengan menawarkan berbagai fasilitas dan tentunya kemudahan berinvesasi. Adanya persaingan dalam menarik calon investor tersebut suatu hal yang tidak dapat dihindarkan, mengapa? Karena kehadiran investor dalam menggerakkan berbagai roda perekonomian, merupakan sebuah kondisi yang tidak bisa diabaikan begitu saja, mengingat untuk melakukan pembangunan di berbagai sektor dana pemerintah sangat terbatas. Oleh karena itu, langkah yang tepat dalam hal ini adalah mengundang investor. Di sisi lain, investor pun secara naluri bisnis terus mengembangkan usahanya ke berbagai tempat, di mana ada peluang di situlah investor menanamkan modalnya. Peluang yang dimaksud di sini tentu ada kaitannya dengan regulasi dalam melakukan kegiatan usaha terkait dengan perizinan. Apakah peraturan perudang-undangan di negara atau daerah tujuan untuk melakukan investasi memerlukan berbagai persyaratan yang harus dipenuhi oleh investor dan prosedur untuk mendapatkan perizinan cukup sederhana ataukah rumit?

Apa yang menjadi pertimbangan investor tersebut dapat dipahami bahwa untuk melakukan kegiatan investasi, yakni masalah perizinan. Di sisi lain Pemerintah Indonesia, membuka seluas-luasnya kepada para calon investor dapat melakukan investasi di dalam berbagai sektor. Jika dilihat dari sudut pandang ini, tentu hal ini cukup menarik bagi investor untuk menanamkan modalnya, mengapa? Karena secara konseptual pada dasarnya semua bidang usaha dapat dimasuki oleh investor. Namun di sisi lain dikemukakan, untuk melakukan investasi di Indonesia wajib memperoleh izin. Demikian ditegaskan dalam Pasal 25 ayat (4) UUPM. Bila demikian halnya, izin apa saja yang harus 
dilengkapi oleh calon investor ketika hendak melakukan investasi; kemana izin harus diajukan dan siapa berwenang memberikan izin? Dalam Pasal 25 ayat (5) UUPM hanya dikemukakan: Izin sebagaimana dimaksud pada ayat (4) diperoleh melalui pelayanan satu pintu terpadu. Lebih lanjut tentang hal ini dijabarkan dalam Pasal 27 ayat (2) UUPM: Pelayanan terpadu satu pintu dilakukan oleh lembaga atau instansi yang berwenang di bidang penanaman modal yang mendapat pendelegasian atau pelimpahan wewenang dari lembaga atau instansi yang memiliki kewenangan perizinan dan nonperizinan di tingkat pusat atau lembaga atau instansi yang berwenang mengeluarkan perizinan dan nonperizinan di provinsi atau kabupaten/kota.

Dari apa yang dijelaskan dalam ketentuan di atas terlihat, bahwa terkait dengan perizinan yang harus dimiliki oleh pelaku usaha yang hendak melakukan investasi diberikan oleh berbagai instansi yang berwenang untuk itu. Dalam UUPM sendiri dijelaskan Pemerintah mengoordinasikan dalam melaksanakan kebijakan di bidang investasi. Hal ini dijabarkan dalam Pasal 27 UUPM ayat (1): Pemerintah mengoordinasi kebijakan penanaman modal, baik koordinasi antarinstansi Pemerintah, antar instansi Pemerintah dengan Bank Indonesia, antar instansi Pemerintah dengan pemerintah daerah, maupun antar pemerintah daerah; ayat (2):
Koordinasi pelaksanaan kebijakan penanaman modal sebagaimana dimaksud pada ayat (1) dilakukan oleh Badan Koordinasi Penanaman Modal. Untuk mereassikankan tugas yang diemban oleh Badan Koordinasi Penanama Modal diterbitkan sejumlah peraturan dalam menudukung kegiatan investasi.

Mungkin timbul pertanyaan, apa sesungguhnya hakikat perizinan? Untuk menjawab pertanyaan ini, dalam kepustakaan ilmu hukum para ahli memberikan berbagai pendapat tentang hakikat perizinan antara lain, Ivan Fauzani Raharja, mengemukakan izin (verguning) adalah suatu persetujuan dari penguasa berdasarkan undang-undang atau peraturan pemerintah untuk dalam keadaan tertentu menyimpang dariketentuan-ketentuan larangan peraturan perundang-undangan. Izin dapat juga diartikan sebagai dispensasi atau pelepasan/pembebasan dari suatu larangan. Sedangkan perizinan adalah salah satu bentuk pelaksanaan fungsi pengaturan dan bersifat pengendalian yang dimiliki oleh Pemerintah terhadap kegiatan-kegiatan yang dilakukan oleh masyarakat. ${ }^{15}$ Pandangan yang senada juga dikemukakan oleh Nur Asiyah mengemukakan, secara yuridis izin adalah kewenangan administratif yang dimiliki oleh pemerintah sebagai salah satu sarana untuk mengawasi aktivitas masyarakat. Izin adalah persetujuan yang didasarkan pada kekuasaan mengatur pemerintah beralaskan hukum 
dimaksudkan sebagai alat untuk kebaikan bagi masyarakat. ${ }^{16}$

Dari pandangan yang dikemukakan oleh para ahli di atas dapat diketahui bahwa hakikat dari perizinan adalah persetujuan atau diperkenankannya suatu kegiatan yang dilakukan oleh pemohon izin dalam hal ini melakukan kegiatan usaha. Ada pun kewenangan untuk memberikan persetujuan ada di tangan pemerintah sebagai pejabat tata usaha negara. ${ }^{17}$ Wujud dari kewenangan pemerintah dalam memberikan izin dalam rangka untuk mengawasi kegiatan yang dilakukan oleh masyarakat. Dalam kaitannya dengan kegiatan bisnis yakni melakukan investasi, untuk mendapatkan izin diperlukan sejumlah persyaratan yang harus dipenuhi baik yang ditentukan oleh pemerintah pusat maupun oleh pemerintah daerah. Tampaknya disinilah letak problematikanya yang bisa menimbulkan permasalahan dalam pengurusan perizinan yang cukup panjang dan cerndrung birokratis, karena bisa jadi setiap instansi merasa mempunyai kewenagan untuk menetapkan persyaratan yang harus dipenuhi oleh pemohon izin.

Bila terjadi seperti yang digambarkan di atas, dampaknya bisa diperkirakan dapat mengakibatkan waktu pengurusan perizinan akan semakin lama. Pada hal waktu bagi pelaku usaha adalah uang (time is money). Dampak lainnya bisa jadi biaya pengurusan perizinan menjadi mahal dan biaya yang dikeluarkan cukup besar (high cost) oleh pemohon izin. Tentang hal ini dapat dilihat dari berbagai hasil studi yang dilakukan oleh para ahli, antara lain dikemukakan oleh Kiki Meliza dan Robert A. Simanjuntak, terlalu banyaknya izin yang harus dikantongi oleh investor di daerah dan biaya pengurusan yang harus dilakukan menjadi kendala investasi selama ini. Lebih lanjut dikemukakan, iklim usaha yang kondusif akan menjadi tolok ukur dalam melihat kemampuan dan kesiapan suatu daerah guna mengambil manfaat dan peluang dalam investasi. Investasi akan masuk ke suatu daerah apabila daerah tersebut memiliki daya tarik investasi. ${ }^{18}$ Dari berbagai studi yang dilakukan oleh pakar di atas tampak bahwa upaya untuk menarik calon investor dibutuhkan pelayanan perizinan tidak berbelit-belit. Hal ini tentu dapat dipahami mengingat bagi pelaku usaha segala sesuatu harus berdasarkan kemanfaatan dan dihitung secara ekonomi untung dan rugi. Dengan kata lain, apakah biaya yang dikeluarkan tersebut rasional atau tidak.

16 Nur Asiyah, "Strategi Implementasi Perizinan Dan Sanksi Administratif Sebagai Pembatasan Terhadap Kebebasan Bertindak Termuat," Jurnal Hukum Samudra Keadilan Vol 12, No 1 ( Januari-Juni 2017): 132, https://media.neliti.com/media/publications/240387-strategi-implementasi-perizinan-dan-sank-94333c35.pdf, diakses 1 Agustus 2019.

17 Pasal 1 angka 1 Undang-Undang Nomor 5 Tahun 1986 Tentang Peradilan Tata Usaha Negara menjelaskan: Badan atau Pejabat Tata Usaha Negara adalah Badan atau Pejabat yang melaksanakan urusan pemerintahan berdasarkan peraturan perundang-undangan yang berlaku.

18 Kiki Meliza dan Robert A. Simanjuntak. "Pengaruh Desentralisasi Terhadap Masuknya Investasi Pada 32 Provinsi Di Indonesia". 1004, https://jurnal.bppk.kemenkeu.go.id/snkn/article/.../158/, diakasesn Juni 2019. 
Jika tidak rasional tentu pelaku usaha tidak akan menanamkan modalnya di daerah yang hendak dijadikan sasaran investasi. Dalam hal inilah Pemda dituntut agar kreatif untuk memanfaatkan peluang yang ada agar investor mau datang. Dalam kaitan ini menarik pandangan yang dikemukakan oleh Rudy Catur Rohman Kusmayadi, peningkatan investasi daerah akan dapat terwujud jika di daerah terdapat potensi yang dapat "dijual" kepada para investor, baik itu berupa potensi sumber daya alam maupun potensi sumber daya manusia. Kemampuan daerah untuk menjual tersebut harus didukung oleh terciptanya iklim yang kondusif dan mendukung investasi di daerah seperti adanya jaminan keamanan dan kepastian hukum bagi investasi di daerah. Pemerintah Daerah hendaknya juga mampu melahirkan regulasi yang dapat memacu pertumbuhan perekonomian yang mampu merebut investor. ${ }^{19}$

Olehkarenaitu, upayayangharus dilakukan dalam hal menarik calon investor agar tertarik untuk menanamkan modalnya perlu ada peta investasi yang jelas baik potensi daerah, sumber daya manusia dan juga memotong mata rantai birokrasi perizinan yang panjang yang pada akhirnya bisa menimbulkan biaya ekonomi tinggi. Untuk bisa mencapai kearah kesederhanaan perizinan, tidak ada jalan lain bagi para pelayan publik harus memahami hakikat tugas yang dibebankan kepadanya, semata-mata untuk melayani kepentingan publik dengan sungguh-sungguh dan sepenuh hati. Seperti diketahui, jika dilihat dari sudut pandang pelayanan publik (public service) layanan publik untuk menadapatkan izin sudah seharusnya dapat dinikmati oleh warganya yang ingin meminta layanan publik. Dalam kaitan ini menarik apa yang dikemukakan oleh Safri Nugraha, kegiatan pemerintahan, baik yang bersifat rutin maupun pembangunan, salah satu yang dijalankan adalah memberikan pelayanan kepada masyarakat (public service). Salah satu bentuk pelayanan untuk masyarakat adalah izin yang hanya dapat diperoleh dari pemerintah sebagai penyelenggara Pemerintahan Negara dapat menjankan usaha di lingkungan masyarakat. ${ }^{20}$ Hal ini tentu cukup beralasan warga mendapat layanan dari penyelenggara negara, karena warga telah membayar apa yang menjadi kewajibannya dalam hal ini membayar pajak yang ditetapkan oleh negara. Namun rupanya, bisa jadi penyelenggara negara mempunyai alasan lain mengapa penerbitan perizinan tidak serta merta dapat dikeluarkan, ketika permohonan diajukan oleh warganya dalam hal ini pelaku usaha. Jika alasan yang digunakan untuk perlu menganalisis terlebih dahulu dampak yang akan muncul dengan diterbitkannya perizinan, apakah

19 Rudy Catur Rohman Kusmayadi. "Kewenangan Pemerintah Daerah Dalam Penyelenggaraan Investasi Daerah" Jurnal Pusaka edisi Juli Des 2015. Hlm 71. Tersedia di http://webcache.googleusercontent. com/search?q=cache:0vzF6UKPK3EJ:ejournal.alqolam.ac.id/index.php/jurnal_pusaka/article/ download/34/43/+\&cd=2\&hl=en\&ct=clnk\&gl=id, diunduh 15 Agustus 2019.

20 Safri Nugraha. "Landasan Teoritis Dan Yuridis Prosedur Perizinan Di Lingkungan Departemen Perhubungan," Hukum dan Pembangunan (Februari 1997): 24. 
dengan diberikannya izin tersebut, masih tetap terjagakah keseimbangan kepentingan antara pelaku usaha, masyarakat, lingkungan sehingga kegiatan usaha dapat berjalan sesuai dengan apa yang direncanakan, kehidupanan masyarakat tidak terganggu dan lingkungan tetap terpelihara adalah cukup beralasan, mengapa alasan tidak bisa segera diterbitkan. Oleh karena itu perlu pertimbangan yang matang dari berbagai sudut pandang sebelum izin diberikan. Tampaknya di sinilah dibutuhkan koordinasi antar instansi dan masyarakat pun perlu diajak untuk berbicara. Dengan cara seperti ini, maka tujuan mengundang investor agar tercapai yakni membuka lapangan kerja, memberikan devisa dan alih teknologi. Menjadi tidak wajar jika tidak ada alasan untuk menunda-menunda penerbitan izin yang dimohonkan oleh pelaku usaha. Tentunya dalam hal ini bagi pelaku usaha butuh ada kepastian kapan izin akan diterbitkan. Untuk itu, dirasakan perlu ada suatu standar dalam pelayanan perizinan.

Bagaimana mengatasi masalah ini, berbagai langkah pun telah dilakukan oleh pemerintah yakni dengan menyederhanakan berbagai proses perizinan, antara lain pemerintah menerbitkan Peraturan Presiden Republik Indonesia Nomor 27 Tahun 2009

Tentang Pelayanan Terpadu Satu Pintu Di Bidang Penanaman Modal (Perpres No 27/2009). Dalam Pasal 1 Angka 4 dikemukakan: Pelayanan Terpadu Satu Pintu, yang selanjutnya disingkat PTSP adalah kegiatan penyelenggaraan suatu perizinan dan nonperizinan yang mendapat pendelegasian atau pelimpahan wewenang dari lembaga atau instansi yang memiliki kewenangan perizinan dan nonperizinan yang proses pengelolaannya dimulai dari tahap permohonan sampai dengan tahap terbitnya dokumen yang dilakukan dalam satu tempat. Dilihat secara normatif pelayanan yang dilakukan dalam bidang perizinan dalam satu atap adalah suatu yang ideal. Permohonan dapat diputuskan secara cepat.

Namun upaya ini juga belum mendapatkan hasil yang diharapkan. Seperti yang dikemukakan oleh Y. Sri Pudyatmoko, sekalipun pemerintah di sebagian daerah telah mengusahakan unit pelayaran perizinan terpusat, hal ini tidak selalu berhasil memotong dan menyederhanakan prosedur perizinan. Lebih lanjut dikemukakan oleh pakar hukum administrasi ini, kepastian dalam proses penyelesaian permohonan perizinan tidak hanya menyangkut waktu, akan tetapi juga soal biaya, apa yang tercantum dalam ketentuan normatif, misalnya di peraturan daerah telah ditentukan besarnya biaya dalam praktik lebih besar. $^{21}$

Memperhatikan terjadinya berbagai kelambanan untuk mendapatkan perizinan dalam melakukan investasi, pemerintah menerbitkan serangkain kebijakan untuk mempercepat arus investasi, pemerintah melakukan terobosan dengan menerbitkan PP 24/2018. Lembaga pelayanan perizinan 
dikelola secara elektronik yang lebih dikenal dengan Online Single Submission (OSS). Secara konseptual, dengan kehadirian lembaga OSS dalam pengeloaan perizinan, sejatinya dapat mempermudah proses perizinan dalam melakukan investasi, mengapa? Karena pengurusan perizinan tidak lagi dilakukan secara manual dan tatap muka melainkan dilakukan secara elektronik. Untuk itu peluang untuk menyalahkangunakan kewenangan semakin diperkecil. Sebagaimana dikemukakan oleh I Ketut Hadi Priatna, konsep perizinan melalui OSS yakni: menggunakan satu portal nasional; satu identitas perizinan berusaha (NIB) dan satu format izin berusaha (Izin Usaha dan Izin Operasional/Komersial). Perizinan Berusaha diterbitkan berdasarkan Komitmen yang harus dipenuhi oleh Pelaku Usaha; Pemenuhan komitmen diselesai kan di Kementerian/Lembaga dan/atau Pemda. ${ }^{22}$

Sebagai tindak lanjut diterbitkannya PP 24/2018 Badan Koordinasi Penanaman Modal menerbitkan Peraturan Kepala Badan Koordinasi Penanaman Modal Republik Indonesia Nomor 6 Tahun 2018 Tentang PedomanDan Tata Cara Perizinan DanFasilitas Penanaman Modal (PerkaBKPM No 6/2018). Ada hal yang cukup mendasar dalam Perka BKPM ini rezim perizinan diubah menjadi rezim pendaftaran. Sebelum diterbitkanya perka ini, tahapan yang harus dilalui oleh pelaku usaha yakni mendirikan badan usaha terlebih dahulu agar bisa mendapatkan izin usaha. Setelah pendirian usaha dan mendapat izin usaha, diwajibkan untuk melakukan pendaftaran badan usaha agar bisa melakukan kegiatan usaha. Prosedur yang harus diikuti seperti ini tentunya memakan waktu yang cukup lama. Dalam rangka mempercepat kegiatan berusaha tahapan untuk mengurus perizinan dilakukan melalui pendaftaran yang dikelola oleh lembaga OSS.

Hal ini dijelaskan dalam Pasal 1 angka 16 PerkaBKPM No 6/2018: Perizinan Berusaha adalah pendaftaran yang diberikan kepada Pelaku Usaha untuk memulai dan menjalankan usaha dan/atau kegiatan dan diberikan dalam bentuk persetujuan yang dituangkan dalam bentuk surat/keputusan atau pemenuhan persyaratan dan/atau Komitmen. Bagaimana melakukan pendaftaran kegiatan usaha. Hal ini dilakukan dengan secara terintgrasi secara elektronik. Tepatnya dalam Pasal 4 ayat (3) dikemukakan: Perizinan Penanaman Modal selain perizinan sebagaimana dimaksud pada ayat (2), dilaksanakan melalui sistem OSS sesuai dengan ketentuan dalam Peraturan Pemerintah yang mengatur mengenai perizinan berusaha terintergrasi secara elektronik. Lebih lanjut dalam Pasal 8 (1): Permohonan perizinan sebagaimana dimaksud dalam Pasal 4 ayat (2) dilakukan secara dalam jaringan (daring) melalui SPIPISE; ayat (5): Izin Usaha diterbitkan paling lama 3 (tiga) Hari sejak diterimanya permohonan yang lengkap dan benar dan ayat (6): Perubahan Izin Usaha

22 I Ketut Hadi Priatna, Pelaksanaan Sistem Online Single Submission Dan Pokok-Pokok Peraturan Pemerintah Nomor 24 Tahun 2018" (Bandung: 12 November 2018), hlm.22. 
diterbitkan paling lama 3 (tiga) Hari sejak diterimanya permohonan yang lengkap dan benar.

Dengan diterbitkannya serangkaian peraturan perundang-undangan di atas, secara normatif sudah mendapatkan kepastian hukum. Hal ini tentu menjadi peluang besar bagi calon investor. Seperti dikemukakan oleh Boedi Rheza, perizinan, sebagai salah satu pintu masuk investasi swasta, sudah selayaknya dikelola dengan baik. Pelayanan perizinan yang mendukung lancaranya kegiatan berusaha dapat menjadi daya tarik tersendiri bagi pelaku usaha. Beberapa hal yang dilakukan oleh pemda berupa kemudahan dalam memperoleh izin, seperti pengurangan hari pengurusan, kemudahan dalam proses pengajuan, persyaratan memperoleh izin dan lainnya. Beberapa daerah sudah melakukan proses tertentu untuk menciptakan kemudahan dalam perizinan melalui langkah penyederhaan (deregulasi) kebijakan izin. ${ }^{23}$

\section{B. Upaya Yang Harus Dilakukan Untuk Mengatasi Berbagai Hambatan dalam Melakukan Pelayanan Investasi Terintegrasi Secara Elektronik}

Jika dilihat dari sudut pandang tataran normatif, kehadiran lembaga OSS tidaklah berlebihan bila dikemukakan berbagai hambatan dalam pengurusan perizinan berinvestasi dapat dipangkas berbagai rantai birokrasi yang selama ini dianggap sebagai hambatan dalam mengurus perizinan. Hal ini tentunya kurang menguntungkan dengan semangat membangun dimulai dari daerah. Dengan semangat ini, tentunya yang mempunyai peran yang cukup besar adalah para kepala daerah perlu meningkatkan pelayanan publik yang dibutuhkan oleh masyarakat khususnya para pelaku usaha. Adapun arti pentingnya kehadiran investasi di daerah, dapat dilihat dari berbagai studi yang telah dilakukan oleh berbagai pihak, antara lain seperti dikemukakan oleh Delly Mustafa, terselenggaranya pelayanan perizinan yang baik akan menjadi driving force bagi kemajuan ekonomi daerah. Hubungan ini yang sebenarnya belum terlihat di semua daerah karena pada tataran implementasi hanya beberapa daerah yang mampu memanfaatkan momentum otonomi daerah untuk mereformasi sekaligus mengintegrasikan lembaga di tingkat daerah untuk menciptakan pelayanan perizinan yang berkualitas. ${ }^{24}$

Dari apa yang dijabarkan di atas, tampak bahwa belum terciptanya sinergi di antara pimpinan daerah dalam mendorong terciptanya iklim ivestasi yang kondusif. Sebagaimana dikemukakan oleh Iqbal Damanik, produk hukum yang harmonis di pusat dan di daerah memberikan kepastian hukum penyelenggaraan izin. Jika kedua 
hal tersebut tercapai, proses pengurusan izin menjadi lebih pasti dan efisien. Lebih jauh lagi, pertumbuhan ekonomi di daerah akan terdorong, karena iklim investasi semakin baik dengan adanya penyederhanaan izin. ${ }^{25}$ Dalam suasana seperti ini, diperlukan adanya pemahahan bersama bahwa pelayanan yang diberikan oleh pejabat publik tujuan akhirnya adalah untuk kesejahteran bersama. Akan tetapi dalam tataran implementasi kebijakan yang sudah dirancang sedemikan rupa, adakalanya jauh dari harapan.

Sebagaimana dapat dibaca dari laporan Badan Pembinaan Hukum Nasional, sejatinya peraturan perundang-undangan yang dikeluarkan oleh Pemerintah akhirakhir ini adalah untuk memberikan gairah atau dorongan para investor untuk menanamkan modalnya. Tetapi apakah peraturan perundang-undangan yang ada sekarang ini yang jumlahnya sangat banyak dapat memberikan dorongan berinvestasi atau justru menghambat investasi? ${ }^{26}$ Hal ini tentu memperkuat argumentasi, peraturan yang diterbitkan yang saling tumpang tindih bisa menimbulkan berbagai implikasi dalam tataran pelaksaaannya. Bisa jadi setiap lembaga merasa paling merasa benar sendiri. Akibat lebih jauh, bagi pelaku usaha dengan tidak adanya sinkronisasi antara satu peraturan dengan peraturan lainnya bisa menimbulkan ketidakpastian berusaha. Tentu iklim investasi seperti ini akan menghambat masuknya investasi. Oleh karena itu, tidak mengherankan jika ada yang berpandangan kondisi saat ini sedang terjadi hiperregulasi. Untuk mengurasi regulasi yang dimaskud, maka kehadiran Omnibus Law dapat menjadi solusi dari adanya hiperregulasi menuju sinkronisasi dan harmonisasi peraturan perundang-undangan. ${ }^{27}$

Sementara itu investasi dibutuhkan untuk pembangunan, seperti yang dikemukakan oleh Suparno, investasi merupakan salah satu komponen penting dalam pembangunan ekonomi karena mempunyai keterkaitan dengan keberlangsungan kegiatan ekonomi di masa yang akan datang. Dengan melakukan investasi, kapasitas produksi dapat ditingkatkan, yang berarti peningkatan output. Pengembangan investasi di daerah, selain untuk meningkatkan kapasitas ekonomi daerah yang secara langsung akan meningkatkan kesejahteraan masyarakat secara umum, juga akan berdampak positif bagi peningkatan kapasitas fiskal daerah. ${ }^{28}$ Hal ini tentu

25 Iqbal Damanik. op.cit, hlm 15.

26 Badan Pembinaan Hukum Nasional. Laporan Akhir Analisis Dan Evaluasi Hukum Mengenai Mekanisme Perizinan Dalam Rangka Mendukung Kemudahan Berinvestasi Di Indonesia. (Jakarta: Pusat Analisis Dan Evaluasi Hukum Nasional Badan Pembinaan Hukum Nasional Kementerian Hukum Dan Hak Asasi Manusia, 2016), hlm. 11.

27 Muhamad Azhar. "Omnibus Law sebagai Solusi Hiperregulasi Menuju Sinkronisasi Peraturan Per-Undangundangan di Indonesia”. Jurnal Adminitrative Law \& Governance Journal Vol. 2, Issue 1, (March 2019), https://ejournal2.undip.ac.id/index.php/alj/article/view/6671, diakses 24 November 2020

28 Suparno. Inovasi Daerah Untuk Meningkatkan Iklim Investasi. Mimbar Administrasi Vol. 1, No. 1, (Oktober 2017): 8 . 
sejalan dengan apa yang dijelaskan dalam UUPM: Tujuan penyelenggaraan penanaman modal, antara lain untuk: a. meningkatkan pertumbuhan ekonomi nasional; b. menciptakan lapangan kerja; c. meningkatkan pembangunan ekonomi berkelanjutan; d. meningkatkan kemampuan daya saing dunia usaha nasional; e. meningkatkan kapasitas dan kemampuan teknologi nasional; f. mendorong pengembangan ekonomi kerakyatan; g. mengolah ekonomi potensial menjadi kekuatan ekonomi riil dengan menggunakan dana yang berasal, baik dari dalam negeri maupun dari luar negeri; dan h. meningkatkan kesejahteraan masyarakat (Lihat Pasal 4 ayat 2).

Yang menjadi pertanyaan adalah, bagaiman mewujudkan tujuan penanaman modal yang dimaksud? Dalam hal ini diperlukan iklim kondusif dalam melakukan investasi sehingga investor merasa nyaman dan aman serta terlindungi hak-haknya dalam melakukan keigatan investasi. Di sisi lain, negara atau daerah penerima modal perlu mejaga agar lingkungan dan masyarakat penerima investasi terlindungi hak-haknya. Untuk itu dalam konteks ini, negara perlu menetapkan persyaratan yang harus dipenuhi oleh calon investor. Untuk itulah kehadiran negara lewat pemberian izin menjadi hal yang sangat substansial yakni sebagai tindakan preventif. Di sini terlihat bagaimana negara hadir lewat pranata hukum perizinan untuk memberikan perlindungan, seperti yang dikemukakan oleh pakar hukum adminisrasi negara Nuriyanto A. Daim, tujuan pelayanan perizinan adalah untuk pengendalian aktivitas usaha yang dilakukan oleh masyarakat serta melindungi masyarakat lain di lingkungan sekitar yang ada kemungkinan terdampak oleh akvitas usaha. ${ }^{29}$

Yang menarik dalam hal ini adalah bagaimana pengawasan terhadap izin yang telah diberikan. Singkatnya, apakah izin yang telah diberikan dilakukan secara konsisten ataukah disimpangi demi kepentingan perusahaan untuk mencari keutungan yang sebesar-besarnya? Dalam kaitan ini menarik apa yang dikemukakan oleh Edward James Sinaga, dengan mengutip pendapat Leonard J. Thenberge, mengemukakan kebutuhan akan hukum yang dapat diprediksi dinilai penting bagi negeri yang sebagian besar rakyatnya, memasuki hubungan-hubungan ekonomi melampaui lingkungan sosial yang tradisional. Aspek keadilan, seperti perlakuan yang sama dan standar pola tingkah laku pemerintah, diperlukan untuk menjaga mekanisme pasar dan mencegah birokrasi yang berlebihan. Peraturan perundang-undangan atau kebijakan yang dikeluarkan oleh pemerintah telah memberikan dorongan kepada para investor untuk menanamkan modalnya. ${ }^{30}$

29 Nuriyanto A. Daim. Hukum Perizinan. Pelayanan Perizinan Terpadu Berbasis Teknologi Informasi Dalam Perspektif Good Governance. Yogyakarta: LeksBang Justitia, 2019. Hlm 10.

30 Edward James Sinaga. "Upaya Pemerintah Dalam Merealisasikan Kemudahan Berusaha Di Indonesia" Jurnal RechtsVinding Vol.6, No. 3, (Desember 2017): 341. 
Pandangan lain yang cukup menarik terkait dengan fungsi ganda perizinan dikemukan oleh Delly Mustafa, dalam praktiknya, ranah perizinan usaha sebagai bagian dari pelayanan publik pada era otonomi daerah memiliki dua sisi yang saling bertolak belakang. Sisi pertama dapat dilihat sebagai ruang inovasi kebijakan bagi pemerintah daerah untuk menarik calon investor sehingga berbagai kemudahan yang ditawarkan agar roda investasi dapat berputar. Namun, sebaliknya sisi kedua dilihat sebagai peluang daerah untuk memperbesar Pendapatan Asli Daerah melalui berbagai retribusi yang mungkin dikenakan dari proses perizinan yang dilakukan. ${ }^{31}$

Tampaknya makna perizinan dewasa ini telah terjadi perubahan paradigma. Dalam kaitan ini menarik menyimak apa yang dikemukakan oleh Tatiek Sri Djatmiati, dalam perkembangan perizinan di Indonesia, telah terjadi pergeseran tujuan pemberian izin. Tujuan izin sebagai instrumen yuridis untuk mengendalikan kehidupan masyarakat, beralih menjadi instrumen sumber pendapatan, tidak hanya pemerintah Pusat tetapi juga Daerah. ${ }^{32}$ Merujuk kepada pendapat yang dikemukakan oleh pakar hukum adminstrasi ini, semakin menguatkan pemikiran bahwa pemberi izin dalam hal ini pemerintah baik pusat maupun daerah akan menggunakan instrumen hukum perizinan untuk mendapatkan sumber pendapatan. Tentu bagi pelaku usaha yang hendak melakukan kegiatan investasi perlu melakukan kajian lebih saksama agar biaya yang harus dikeluarkan untuk menguru perizinan masih dalam batas rasional dalam sudut pandang bisnis. Dan sebaliknya bagi pemberi izin perlu juga mengkaji ulang, apakah masih tepat isntrumen perizinan dijadaikan sebagai sumber pendapatan. Hal ini penting, sebab secara normatif perlakuan dalam pemberian izin antara pemodal dalam negeri dengan pemodal asing tidak dibedakan. Yang membedakan adalah untuk bidang usaha tertentu bagi pemodal asing tertutup, sebagaimana diatur dalam daftar negatif investasi.

Jika demikian halnya, maka keinginan untuk mempercepat proses perizinan sebagaimana yang dijabarkan dalam PP 24/2018 akan mengalami hambatan. Hambatan yang dimaksud di sini, selain dari substansi yang harus dilengkapi oleh pemohon izin, misalnya identitas diri badan usaha harus disiapkan sebelum diajukan permohonan pendaftaran. Selain itu, sumber daya manusia yang mengelola teknlologi informasi juga harus disiapkan sehingga memiliki kompetensi yang profesional dalam memberikan layanan kepada publik.

31 Delly Mustafa. Op.Cit. hlm. 43.

32 Tatiek Sri Djatmiati. "Perizinan Sebagai Instrumen Yuridis Dalam Pelayanan Publik”. Pidato Pengukuhan Jabatan Guru Besar Dalam Bidang Hukum Administrasi pada Fakultas Hukum Universitas Airlangga (Surabaya 24 Novembar 2007): 5, http://repository.unair.ac.id/71258/1/KKB\%20KK\%20PG-33-11\%20 Dja\%20p.pdf, diakses 23 Agustus 2019 


\section{Penutup}

1. Secara nomatif diterbitkanya Peraturan Pemerintah Nomor 24 Tahun 2018 terkait dengan masalah perizinan telah diatur secara terpusat dalam hal ini oleh lembaga OSS. Sekalipun perizinan berivestasi telah diatur secara elektronik, namun tidak berarti semua masalah dalam kegiatan investasi akan teratasi secara tuntas. Untuk itu, bagaimana merealisasasikan apa yang dijabarkan dalam peraturan pemerintah tentang pelayanann perizinan secara elektronik, dibutuhkan persamaan persepsi dari semua pihak. Selain itu perlu menyiapkan perangkat teknologi yang siap untuk dioperasikan setiap saat. Kesiapan sumber daya manusia yang mengoperasikan sistem pelayanan perangkat teknologi pelayanan perizinan secara elektronik perlu terus ditingkatkan. Bila semua pihak sudah siap, maka kehadiran peraturan pemerintah tentang pelayanan secara elektronik bisa jadi menjadi solusi dalam mengatasi masalah perizinan investasi. Dan sebaliknya, bisa jadi kehadiran pelayanan OSS menjadi masalah baru dalam perizinan, karena berbagai persiapan baik sarana maupun prasarana belum tersedia. Dan juga tidak kalah penting adalah masalah pembagian kewenangan antar lembaga yang merasa paling berhak untuk mengeluarkan izin investasi. Namun terlepas dari itu semua, pengurusan proses perizinan dilakukan secara elektronik adalah salah satu upaya untuk mempercepat proses perizinan untuk melakukan investasi. Sekalipun demikian tidak berarti berbagai hambatan dalam melakukan berivestasi secara otomatis akan teratasi.

2. Upaya yang harus dilakukan dalam mengatasi berbagai hambatan investasi diperlukan adanya satu pandangan yang sama tentang arti pentingnya kehadiran investasi. Dengan cara pandang yang sama, maka berbagai peraturan yang akan diterbitkan oleh pihak yang mempunyai otoritas untuk itu, dalam rangka menggerakkan investasi sejak awal dapat dilakukan sinkronisasi dan harmonisasi peraturan yang terkait dengan ivestasi sehingga tidak saling bertentangan dengan peraturan lainnya. 


\section{DAFTAR PUSTAKA}

\section{Buku}

Pudyatmoko, Y. Sri. Perizinan Problema Dan

Upaya Pembenahan. Jakarta: Grasindo, 2009.

Daim, Nuriyanto A. Hukum Perizinan. Pelayanan Perizinan Terpadu Berbasis Teknologi Informasi Dalam Perspektif Good Governance. Yogyakarta: LeksBang Justitia, 2019.

\section{Jurnal}

Adrianty, Santhy Ainun; Lydia Goutama dan Nadya Rizky Nakayo. "Kewenangan Badan Koordinasi Penanaman Modal Pasca Berlakunya OSS." Jurnal Perspektif Hukum Vol. 19 No.2, (November 2019) : 250-262. file://C:/Users/Acer/AppData/Local/ Temp/209-384-1-SM.pdf. diaskses 24 Nopember 2020

Ansari, Muhammad Insa. "Omnibus Law Untuk Menata Regulasi Penanaman Modal." (Omnibus Law For Arranging Investment Regulation). Jurnal RechtsVinding, Vol. 9, No. 1, (April 2020). https://rechtsvinding.bphn. go.id/artikel/5.\%20Muhammad\%20 Insa\%20Ansari.pdf, Diakses 24 Nopember 2020

Arrum, Desi Arianing:"Kepastian Hukum Dalam Perizinan Berusaha Terintegrasi Secara Elektronik (Online Single Submission) di Indonesia" Jurnal
Jurist-Diction Vol. 2, No. 5, (September 2019). https://e-journal.unair.ac.id/ JD/article/view/15222. Diakses 24 Nopember 2020

Azhar, Muhamad. "Omnibus Law sebagai Solusi Hiperregulasi Menuju Sinkronisasi Peraturan Per-Undangundangan di Indonesia". Jurnal Adminitrative Law \& Governance Journal Vol. 2, Issue. 1, (March 2019) https://ejournal2.undip.ac.id/index. php/alj/article/view/6671. diakses 24 Nopember 2020

Baidarusa, Muhammad dkk. "Tinjauan Atas Regulasi Penanaman Modal Guna Meningkatkan Ketertarikan Investasi Infrastruktur Strategis Di Indonesia." Jurnal BPPK Vol. 11, No.1, (2018): 75-86. file:///C:/Users/Acer/ AppData/Local/Temp/163-Article\%20 Text-1444-1-10-20180823.pdf. Diakses 24 Nopember 2020

Busroh, Firman Freaddy. "Konseptualisasi Omnibus Law Dalam Menyelesaikan Permasalahan Regulasi Pertanahan". Jurnal Arena Hukum Vol. 10, No. 2, (Agustus 2017): 227-250. https:// arenahukum.ub.ac.id/index.php/arena/ article/viewFile/327/269. Diakses 24 Nopember 2020.

Fauzani Raharja, Ivan. "Penegakan Hukum Sanksi Administrasi Terhadap Pelanggaran Perizinan.” Jurnal 
Inovatif Vol. VII, No. II (Mei 2014).

https://media.neliti.com/media/ publications/65220-ID-penegakanhukum-sanksi-administrasi-terh.pdf. Diakses 8 Agustus 2019.

Kusmayadi, Rudy Catur Rohman. "Kewenangan Pemerintah Daerah Dalam Penyelenggaraan Investasi Daerah" Jurnal Pusaka edisi Juli Des 2015. Hlm 71. Tersedia di http:// webcache.googleusercontent.com/ ch?q=cache:0vzF6UKPK3EJ:ejournal. alqolam.ac.id/index.php/jurnal_ pusaka/article $/ \mathrm{d} / 34 / 43 /+\& \mathrm{~cd}=2 \& \mathrm{hl}=\mathrm{e}$ $\mathrm{n} \& \mathrm{ct}=\mathrm{clnk} \& \mathrm{gl}=\mathrm{id}$, diakses 15 Agustus 2019.

Meliza, Kiki dan Robert A.Simanjuntak. "Pengaruh Desentralisasi Terhadap Masuknya Investasi Pada 32 Provinsi Di Indonesia”. https://jurnal.bppk. kemenkeu.go.id/snkn/article/.../158/. Diakses 1 Juni 2019.

Mustafa, Delly. "Potret Pelayanan Perizinan pada Era Otonomi Daerah" Jurnal Kebijakan Publik Vol. 3, No. 1, (Maret 2012): 1-57. https://ejournal. unri.ac.id/index.php/JKP/article/ view/1539/0. Diakses 1 Juli 2019

Nugraha, Safri. "Landasan Teoritis Dan Yuridis Prosedur Perizinan Di Lingkungan Departemen Perhubungan". Jurnal Hukum dan Pembangunan. (Februari 1997).

Nurhayati, Irna dkk. "Pendaftaran Badan Usaha Secara Elektronik Pasca
Diterbitkannya Peraturan Pemerintah Nomor 24 Tahun 2018" (Electronic Registration of Business Post-Issuance of the Government Regulation Number 24 of 2018)" Jurnal Negara Hukum Vol. 10, No. 2, (November 2019) file://C:/Users/Acer/AppData/Local/ Temp/1351-3845-1-PB.pdf. diakases 24 Nopember 2020

Rusmanto, Media Wieky. "Evaluasi Kebijakan Pelayanan Perizinan Dan Non Perizinan Kota/Kabupaten Di Wilayah Provinsi Jawa Barat". Jurnal Ilmiah Magister Ilmu Administrasi (JIMIA) No.2, Tahun XI (Juni 2017).

Sinaga, Edward James. "Upaya Pemerintah Dalam Merealisasikan Kemudahan Berusaha Di Indonesia" Jurnal RechtsVinding Vol. 6, No. 3, (Desember 2017)

Suparno. "Inovasi Daerah Untuk Meningkatkan Iklim Investasi”. Mimbar Administrasi Vol. 1, No. 1, (Oktober 2017): 8.

\section{Media Elektronik}

Amrin, Ali; Dadang Abdullah; M.Yasir Said. "Kebijakan Pemerintah Yang Menjamin Kepastian Hukum Dalam Berinvestasi Di Daerah." Dalam Prosiding Seminar Nasional Lingkungan Lahan Basah Volume 4 Nomor 2 Halaman 369-372 April 2019. Tersedia di: https:// snllb.ulm.ac.id/prosiding/index.php/ snllb.../216. diakses 10 Juni 2019. 
Asiyah, Nur. "Strategi Implementasi Perizinan Dan Sanksi Administratif Sebagai Pembatasan Terhadap Kebebasan Bertindak Termuat" Jurnal Hukum Samudra Keadilan Volume 12, Nomor 1, Januari-Juni 2017. Hlm 132. Tersedia di https://media.neliti.com/ media/publications/240387-strategiimplementasi-perizinan-dan-sank94333c35.pdf. Diakses 1 Agustus 2019 Badan Pembinaan Hukum Nasional. Laporan Akhir Analisis Dan Evaluasi Hukum Mengenai Mekanisme Perizinan Dalam Rangka Mendukung Kemudahan Berinvestasi Di Indonesia. Jakarta: Pusat Analisis Dan Evaluasi Hukum Nasional Badan Pembinaan Hukum Nasional Kementerian Hukum Dan Hak Asasi Manusia, 2016. Tersedia di https://bphn.go.id/data/documents/ mekanisme_perizinan.pdf, diakses Juli 2019

Damanik, Iqbal. "Deregulasi Izin: Melanjutkan Reformasi Perizinan di Daerah". KPPOD Brief Membangun Indonesia dari Daerah. Edisi JanuariMaret 2015. Tersedia di: https://www. kppod.org/brief/download?id=22, Diakses Juli 2019

Djatmiati, Tatiek Sri. "Perizinan Sebagai Instrumen Yuridis Dalam Pelayanan Publik". Pidato Pengukuhan Jabatan Guru Besar Dalam Bidang Hukum Administrasi pada Fakultas Hukum Universitas Airlangga di Surabaya
24 Novembar 2007. Tersedia di: http://repository.unair.ac.id/71258/1/ KKB\%20KK\%20PG-33-11\%20 Dja\%20p.pdf. Diakses 23 Agustus 2019

hukumonline edisi Kamis, 12 Juli 2018. "Potensi Masalah Hukum Pasca Terbitnya PP Perizinan Terintegrasi”.

Priatna, I Ktut Hadi. Pelaksanaan Sistem Online Single Submission Dan PokokPokok Peraturan Pemerintah Nomor 24 Tahun 2018 . Makalah. Bandung, 12 November 2018

Rheza, Boedi. "Menyederhanakan Perizinan, Meraih Investasi”. PPOD Brief Membangun Indonesia dari Daerah. Edisi Januari-Maret 2015. Tersedia di: https://www.kppod.org/brief/ download?id=22. Diakses 1Juli 2019. Tim Peneliti KPPOD Tahun 2017. "Regulasi Usaha di Daerah Kajian Perda Pungutan dan Perizinan" Tersedia di https://www.kppod.org/backend/ files/laporan_penelitian/kajian-perdapungutan-dan-perizinan.pdf . Diakses 13 Agustus 2019.

\section{Peratura Perundang-Undangan}

Undang-Undang Republik Indonesia Nomor 5 Tahun 1986 tentang Peradilan Tata Usaha Negara.

Undang-Undang Republik Indonesia Nomor 25 Tahun 2007 tentang Penanaman Modal. 
Peraturan Pemerintah Republik Indonesia Peraturan Kepala Badan Koordinasi Nomor 24 Tahun 2018 tentang Penanaman Modal Republik Indonesia Pelayanan Perizinan Berusaha Nomor 6 Tahun 2018 tentang Pedoman Terintegrasi Secara Elektronik. Dan Tata Cara Perizinan Dan Fasilitas Peraturan Presiden Republik Indonesia Nomor Penanaman Modal.

91 Tahun 2017 Tentang Percepatan Pelaksanaan Berusaha 